\title{
Feasibility study for houses of worship saving money rather than paying for electricity in a site in Egypt
}

\author{
A. A. Gado, \\ Consultant of new and renewable energy systems \\ dr_aagado@yahoo.com
}

\begin{abstract}
With estimates of the remaining non-renewable energy stocks around the world, it is clear that the era of use Fossil fuel will run out, as high energy prices that affect economic growth worldwide and increase the burden so; we have no choices to devote public resources for developing energy-saving technologies. And make pressing issue and International trends to replace the energy source of oil by an alternative energy source. There are 5571 worship in south delta site that is churches and mosques belonging to the people and 10966 follow the Endowments Authority, that consume $154520 \mathrm{kWh}$ every day or 154.5 MWh every day equivalent to $13286 \mathrm{~kg}$ fuel every day to be burnt equal to $.5 \%$ from total power consumption for this site. On other hand all houses of worship congregations trying to balance their budget and be good stewards of creation, it makes sense to install energy efficiency upgrades and renewable energy systems.
\end{abstract}

Solar energy technology, which can contribute significantly to growth in the coming years, as well as explain how to make economic feasibility of this technology when working to replace the non-renewable energy sector by feeding it through solar energy. There is still great potential for solar technology, and the growth of demand can contribute to the stability of existing jobs in this sector (covering the entire production chain, not just the quantum leap). It can also increase sales rates in the future and provide consumer credit procedures to facilitate the purchase of the technology.

So, this paper discusses a commonly sized solar energy system, anticipated annual solar power produced for the worship, simple payback calculations, and a Life Cycle Cost Analysis (LCCA) for this system. This study is intended to evaluate the overall project's economic viability in its intended location. Also, this paper summarizes the estimated cost solar power with other sources of energy. And the positive impact on reducing greenhouse gas emissions and reducing energy demand on the other hand.

Index Terms-Photovoltaic, peak sunshine hour, depth of discharge, Maximum power point, capital cost, unit energy cost, life cycle cost, interest rate

\section{INTRODUCTION}

Because demand for electricity has grown at alarming rates to meet the needs of society. and

incurs a costly electric bill Due to the depletion of fossil fuels that cause the costs of electricity will rise hardly in the future. as well as Egypt trying to provide hard currency to buy diesel fuel to run the power plants and for concerned about fluctuations in electricity prices, also, changes in the cost or availability of natural gas and other fossil fuels can create dramatic swings in energy costs that pose a threat to National security as a result of failure to meet the requirements of domestic consumer, commercial and industrial electrification because alternative sources of energy besides the fossil fuels that the current infrastructure has become dependent upon.

For all that it is very import to seek another energy sources. expensive solar panels and lack of correct information about solar energy utilization, make fuel-generated electricity a preferable

and Egypt has yet to exert efforts to develop energy from solar resource the government should be the main organization that should lead the development of this energy sector To implement solar energy policies successfully in Egypt , where solar power is now competitive with other sources of energy without emitting the dangerous greenhouse gases that cause climate change. So, solar electric installation will provide a buffer of security

There are 16537 houses of worship lies at site of south delta electrical distribution company that consume collectively 5,274,500 kwh monthly. getting their energy from the same sources that homes and businesses do.

If worship begin purchasing and installing their own solar arrays ,it will begin saving money quicker than if someone else did it for them and The they will be able to make up their money spent and start saving much before the time they need to be replaced because Most solar panels are given a twenty to twenty-five year warranty. The homeowner will be able to make up their money spent and start saving much before the time they need to be replaced

Decision to "go solar" at a house of worship will be about something more than the merits of the financial equation. that save money on energy costs will have more funds to focus on their primary mission on the other hand Solar arrays will decrease the amount of coal and other natural resources used to generate electricity and the 
growth of demand can contribute to the stability of existing jobs in this sector (covering the entire production chain, not just the quantum leap). It can also increase sales rates in the future and provide consumer credit procedures to facilitate the purchase of the technology.

So, the overall goal of this paper was to create an economic model that could predict the feasibility of installing a photovoltaic system on the roof of the Houses of worship. Also, the life cycle cost (LCC) estimation of the designed PV system is discussed. The LCC of an item consists of the total costs of owning and operating an item over its lifetime, expressed in today's money.

\section{PROPOSED MODEL}

The proposed approach includes the calculation of the energy requirements for the study load, design PV system to supply diurnal load, conventional energy conservation due to the generation of PV systems, and the economy of PV system and the electric utility bill of the owner of this system.

\section{1 load demand}

The average daily $\mathrm{kWh}$ load demand $\mathrm{E}_{\mathrm{L}}$ can be calculated from the electrical utility data

\subsection{Sizing of the PV Array}

For battery losses ( $\eta \mathrm{b})$ is about 15\% [9] and the PV thermal losses $\left(\eta_{\text {th }}\right)$ is about $15 \%$ also. The average peak sunshine hour (PSSH) in egypt is about $6 \mathrm{~h}$. The peak power of the PV module can be determined as [1 ]:

Peak power of the PV $\left(\mathrm{PV}_{\mathrm{wp}}\right)=\mathrm{E}_{\mathrm{L}} /\left(\mathrm{PSSH} * \eta_{\mathrm{b}} * \eta_{\mathrm{th}}\right)$

\subsection{Battery Storage}

This type of system incorporates energy storage in the form of a battery to keep The system operating during a utility outage or at night the unit disconnects from the utility and powers specific loads for houses of worship. backup battery system can provide about $8 \mathrm{kWh}$ of energy storage at an 8-hour discharge rate, which means that the battery will operate a 1-kW load for 8 hours which is the average usage for a for houses of worship in the night when there is no air conditions " lighting only and fans circuits are wired from a subpanel that is separate from the rest of the electrical circuits

Considering $80 \%$ maximum depth of discharge (DOD), So we choose battery where the voltage side $24 \mathrm{~V}$, the required maximum battery capacity per day is calculated as [2]:

Battery capacity $\left(\mathrm{Wh}_{\mathrm{b}}\right)=\mathrm{E}_{\mathrm{L}} /\left(\mathrm{DOD} * \eta_{\mathrm{b}}\right)$

\section{4 panel specifications}

The roof space limits the number of panels which limits the power that can be obtained from them, solar panel system would affect the overall amount of energy that the houses of worship could save. a panel's orientation can have a large effect on the amount of solar energy it can gather and power it can generate.
Input data for place site (Cairo and el- Mahalla elkobra) as latitude and longitude are showed in Table 1 [3].

\subsubsection{Maximum power point (MPP)}

the operating point on the I-V curve that gives the maximum output power from the solar cell at different operating conditions which produce maximum values of power points is given by [6] :

$$
\mathrm{I}(\mathrm{V})=\mathrm{Isc}-\mathrm{A}\left(\left(\mathrm{e}^{\wedge} \mathrm{BV}\right)-1\right)
$$

Where; $\mathrm{A}=0.00524$

$$
\mathrm{B}=0.1777
$$

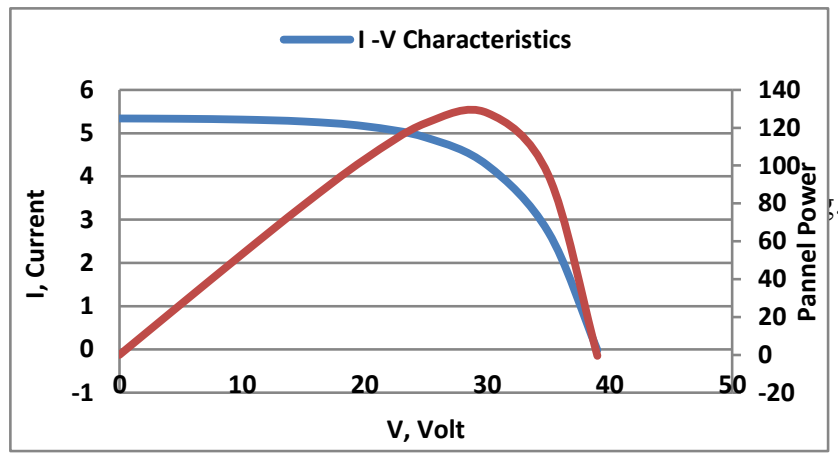

Fig 1. panel specification

Table1 illustrate PV modules of polycrystalline silicon type of $150 \mathrm{~W}_{\mathrm{P}}$ at standard test conditions (i.e., $1000 \mathrm{~W} / \mathrm{m} 2$ and $25^{\circ} \mathrm{C}$ ) .

\begin{tabular}{|c|c|c|}
\hline \multicolumn{3}{|c|}{ TABLE I } \\
\hline Peak power & $150 \mathrm{~W}_{\mathrm{P}}$ & \\
\hline $\mathrm{V}_{\mathrm{oc}}$ & $39 \mathrm{~V}$ & \\
\hline $\mathrm{I}_{\mathrm{sc}}$ & $5,34 \mathrm{~A}$ & \\
\hline Cairo & $30^{\circ} 01^{\prime} \mathrm{N}$ & $31^{\circ} 14^{\prime} \mathrm{E}$ \\
\hline El Mahalla El Kubra & $31^{\circ} \mathrm{'} \mathrm{N}$ & $31^{\circ} \mathrm{'} \mathrm{E}$ \\
\hline
\end{tabular}

\subsection{Charging (Controllers)}

Charge regulators (controllers) are rated based on the amount of amperage they can process from a solar array. Also, the charge controller should be rated at $125 \%$ above the Isc [4 ], For example a controller should be more than 7A (5.34* 1.25).

\subsection{Inverter}

it can be selected as $25 \%$ higher than the rated power of the total AC loads. to handle the maximum expected power of $\mathrm{AC}$ loads.

\section{ESTIMATING SYSTEM OUTPUT}

\subsection{Daily Energy Requirement}

There are 16537 houses of worship that can consume collectively 5,274,500 kwh monthly, the assumption that every worship consumes daily $10354 \mathrm{Wh}$.

So, the daily energy requirements $\mathrm{E}_{\mathrm{dr}}$ for every worship equal :

$$
\mathrm{E}_{\mathrm{dr}}=\mathrm{PV}_{\mathrm{wp}} / \text { No of worship }
$$

\section{2 daily generated energy}

the daily energy generated of PV systems, Ev(a) is given by [5 ]:

Where $\eta_{c}$ and $\eta_{p c}$ are the efficiencies of PV array and power conditions, and $\mathrm{Ht}(\mathrm{a})$ is the annual solar radiation received on the unit area of PV array

$$
\mathrm{E}_{\mathrm{v}}(\mathrm{a})=\mathrm{N}_{\mathrm{m}} * \mathrm{~S}_{\mathrm{vm}} * \mathrm{H}_{\mathrm{t}}(\mathrm{a}) * \dot{\eta}_{\mathrm{c}} * \dot{\eta}_{\mathrm{pc}} / \mathrm{PSSH}
$$




\subsection{Solar Irradiance}

The annual diurnal energy demand and solar radiation are used with the proposed model section 2-2 during year months at cairo and el mahalla el-kobra for area of $18 \mathrm{~m} 2$ for every module

\subsection{Estimating Electrical Energy Savings}

The energy savings to a houses of worship can be estimated by simply multiplying the annual energy in $\mathrm{kWh}$ that a PV system might produce times the utility electric energy

3.6 Economic feasibility of the systems,

Considering capital cost $C C_{v}$ which is developed as a function of peak power of $\mathrm{PV} P_{v p}$ system and the cost of $1 \mathrm{~kW}_{\mathrm{P}}$ equal $1 \$ / 1 \mathrm{~kW}_{\mathrm{P}}$, the the capital, $\mathrm{CCv}$, and the annual capital ACCv, cost of a PV system are studied. Also, The unit energy cost of complimentary conventional $\mathrm{PV}$ generation on the electric utility, $\mathrm{UEC}_{\mathrm{cv}}$ can be modeled as [ 7 ].

$$
\mathrm{CC}_{\mathrm{v}}=\mathrm{c}_{\mathrm{v}} * \mathrm{P}_{\mathrm{vp}}
$$

Where; $\quad \mathrm{P}_{\mathrm{vp}}=\mathrm{Wp} * \mathrm{Nm}$

And $\mathrm{ACCv}=C C_{v} * \mathrm{DR}$

Where $c_{v}$ is the cost per $1 \mathrm{kWp}$ and DR is the annual discount rate.

Considering the savings in conventional fuel, and pollution elimination, costs due to PV generation, $U E C^{\prime}{ }_{v}$ and $U E C^{\prime}{ }_{C V}$ are also calculated .

Considering sum of all the present worth's (PW's) of the costs of the PV modules, storage batteries, inverter, the cost of the installation, and the maintenance and operation cost $(\mathrm{M} \& \mathrm{O})$ of the system. are shown in Table 2 .

\begin{tabular}{|c|c|}
\multicolumn{2}{c}{ TABLE 2} \\
\hline Item & Cost \\
\hline PV Panel & $.5 \$ / \mathrm{W}$ \\
\hline Battery & $1 \$ / \mathrm{Ah}$ \\
\hline Inverter & $0.5 \$ / \mathrm{W}$ \\
\hline Installation & $5 \%$ of PV Cost \\
\hline Maintenance/Year & $10 \%$ of PV Cost \\
\hline
\end{tabular}

\section{APPLICATION}

From the data of the company we assume that each Houses of worship consumes about 10 $\mathrm{kwh} /$ day for 10 hours sun shine it consume $1 \mathrm{kw}$ /day and for safety we design over 5 hours that give maximum solar radiation and at this point every Houses of worship needs $2.4 \mathrm{kw}$ solar array

The size of PV module must be such as to produce $2.4 \mathrm{~kW}$ with operating voltage more than $24 \mathrm{~V}$, in order to charge the batteries

Referred to equation 1 . The system needs approximately 16 PV modules of polycrystalline silicon type of $150 \mathrm{Wp}$ as peak power were selected $\left(\mathrm{I}_{\mathrm{SC}}=5.34 \mathrm{~A}, \mathrm{~V}_{\mathrm{OC}}=39 \mathrm{~V}, \mathrm{Im}=4.26 \mathrm{~A}\right.$, $\mathrm{Vm}=30 \mathrm{~V}$ at STC) have to be organized in subarrays of 16 parallel strings $(16 * 4.26 \mathrm{~A}=68.16$ A), each string connected to the charge controller. The total array peak power is $(4.26 \mathrm{~A} * 39 \mathrm{~V}) *(1$ $* 16)=2.045 \mathrm{kWp}$ Fig $(1)$ shows characteristic of PV panel. Also, Fig (2) illustrate monthly solar radiation on an inclined plane (South facing -Tilted $30^{\circ}$ ) during year months at Cairo and Elmahalla el-kobra for area of $18 \mathrm{~m}^{2}$ for every module. For the studied load of $10 \mathrm{kwh} /$ day and point to equation 2 and for $80 \%$ maximum depth of discharge (DOD) so that it will not be over discharged . the required battery capacity will be approximately $15000 \mathrm{Wh}$, then , battery of $230 \mathrm{AH}$, rating $24 \mathrm{~V}$ that will be needed is to supply the study load which will produce 5520 $\mathrm{Wh}$ connected in series $(230$ Ah $* 24 \quad \mathrm{~V} * 3)$ in total. The battery storage was able to operate for more than $8 \mathrm{~h}$ continuously.

The proposed model is applied numerically to determine the economy of the system, where the most important factor is the interest rate and the future electricity price. The investment analysis was done with interest rates of $10 \%$ and $8 \%$ and with an increased electricity price of 5 or $10 \%$ per year. The expected solar panel lifetime of 25 years. Figures from 3: 9 shows UECv, UEC' ${ }_{v}$, UECcv, UEC',

; UECv is the Unit energy cost for PV system

UECcw is the Unit energy cost of complementary utility and PV system

$\mathrm{UEC}^{\prime} \mathrm{cw}$ is the Unit energy cost of complementary utility and PV system taking into consideration cost of fuel and pollution

UEC'v is the Unit energy cost for PV system taking into consideration cost of fuel and pollution as.

The results also shown in table 3 and in figures 3 , 4, 5,6

Also, LCC of the PV system includes the sum of all the present worth's (PW's) of the costs of the PV modules, storage batteries, inverter, the cost of the installation, and the maintenance and operation cost $(\mathrm{M} \& \mathrm{O})$ of the system have been evaluated and shown in figure 7

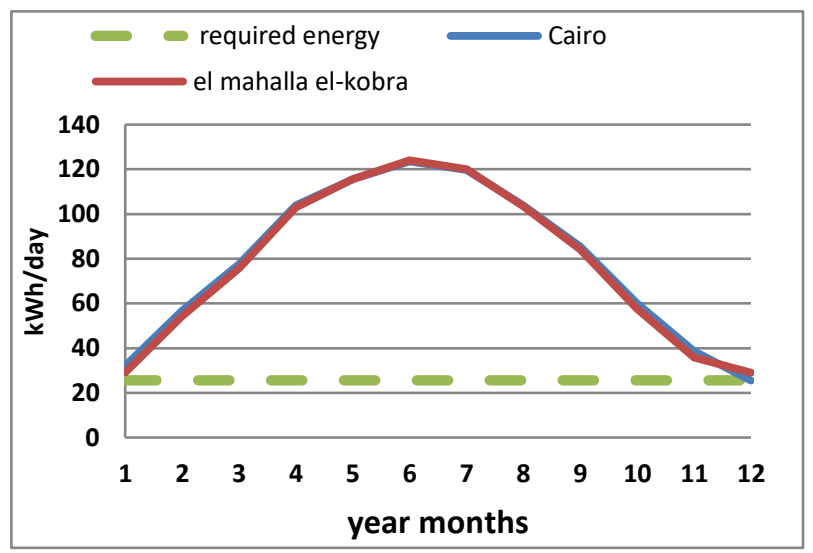

Fig 2. monthly energy output from inclined plane and load demand during year months at Cairo and El- mahalla el-kobra for area of $18 \mathrm{~m}^{2}$ for every module. 


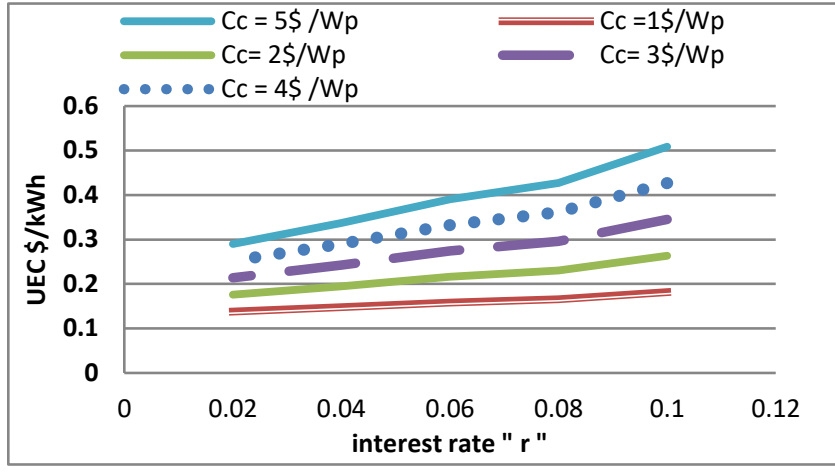

Fig 3 . Relation between UEC \& interest rate

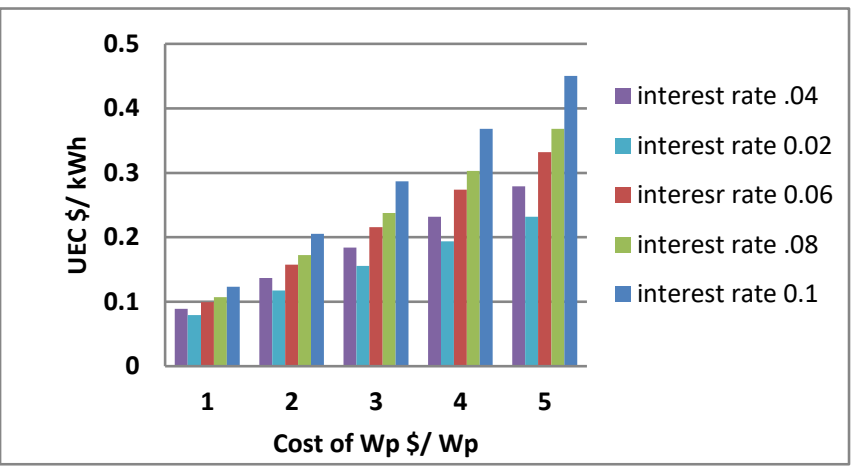

Fig 4. Relation between UECv' \& changing in cost of Wp (tacking into considration cost of fuel and pollution)

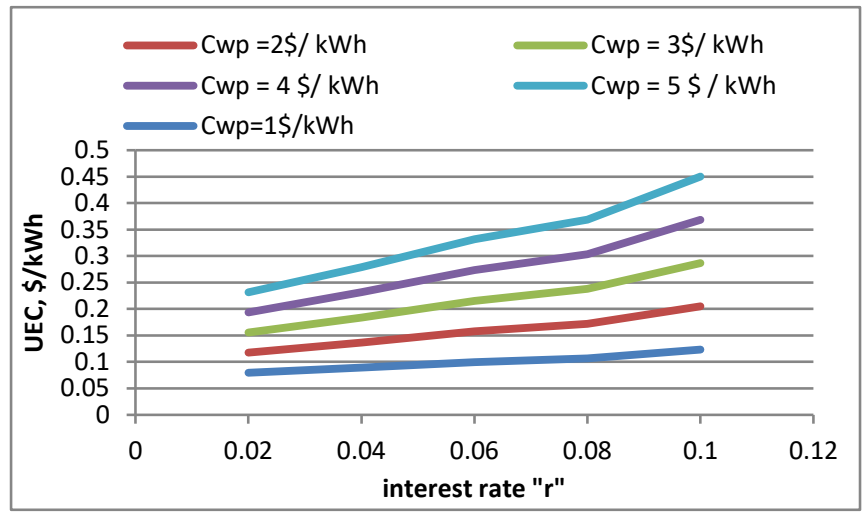

Fig 5. Relation between UECv' \& $\mathbf{r}$ (tacking into considration cost of fuel and pollution)

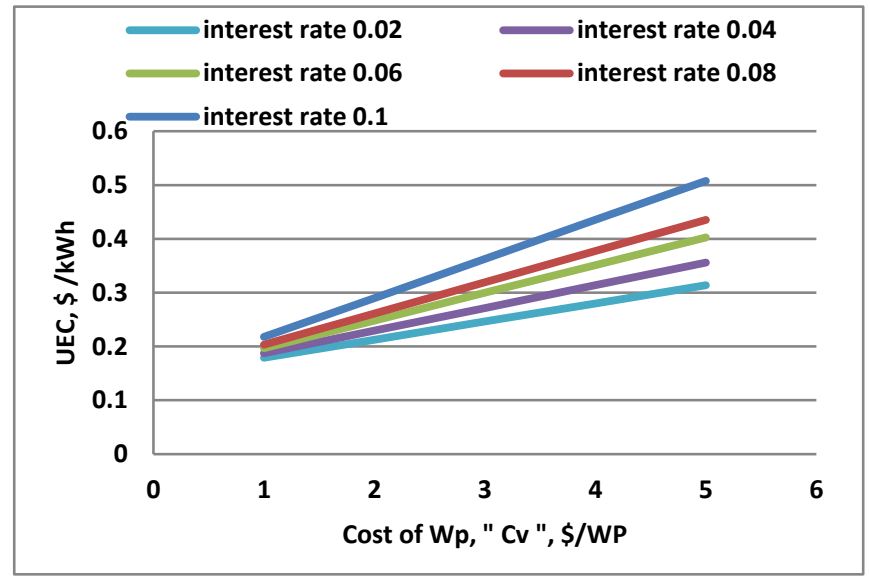

Fig 6. Relation between UECev \& Cost of Wp
TABLEl 3.

\begin{tabular}{|c|c|c|c|c|c|c|}
\hline \multirow{7}{*}{$\mathbf{U E C}_{\mathbf{v}}$, } & \multirow[b]{2}{*}{$\mathbf{r}$} & \\
\hline & & \multicolumn{5}{|c|}{$\frac{\mathbf{C}_{\mathrm{wp}}, \mathbf{\$} / \mathbf{W}_{\mathrm{p}}}{3}$} \\
\hline & .1 & 0.182 & 0.263 & 0.345 & $\mathbf{0 . 4 2 7}$ & 0.509 \\
\hline & .08 & 0.165 & 0.231 & 0.296 & 0.362 & 0.427 \\
\hline & .06 & 0.158 & .216 & .274 & .33 & .39 \\
\hline & .04 & 0.148 & .195 & .242 & .289 & .338 \\
\hline & .02 & .138 & .176 & .214 & .252 & .289 \\
\hline \multirow{5}{*}{$\mathrm{UEC}_{\mathrm{cv}}$} & .1 & .218 & .29 & .36 & .44 & .51 \\
\hline & .08 & .203 & .26 & .32 & .38 & .44 \\
\hline & .06 & .197 & .248 & .299 & .35 & .4 \\
\hline & .04 & .188 & .23 & .27 & .31 & .36 \\
\hline & .02 & .18 & .21 & .25 & .28 & .31 \\
\hline & & & & & & \\
\hline \multirow{5}{*}{$\mathrm{UEC}^{\prime}{ }_{\mathrm{v}}$} & .1 & .12 & .21 & .29 & .37 & .45 \\
\hline & .08 & .11 & .17 & .24 & .3 & .37 \\
\hline & .06 & .099 & .158 & .22 & .27 & .33 \\
\hline & .04 & .09 & .14 & .18 & .23 & .28 \\
\hline & .02 & .08 & .12 & .16 & .19 & .23 \\
\hline & & & & & & \\
\hline \multirow{5}{*}{$\mathrm{UEC}^{\prime}{ }_{\mathrm{cv}}$} & .1 & .166 & .24 & .31 & .39 & .46 \\
\hline & .08 & .15 & .21 & .27 & .33 & .38 \\
\hline & .06 & .15 & .197 & .25 & .299 & .35 \\
\hline & .04 & .14 & .18 & .22 & .26 & .3 \\
\hline & .02 & .128 & .161 & .19 & .23 & .26 \\
\hline
\end{tabular}

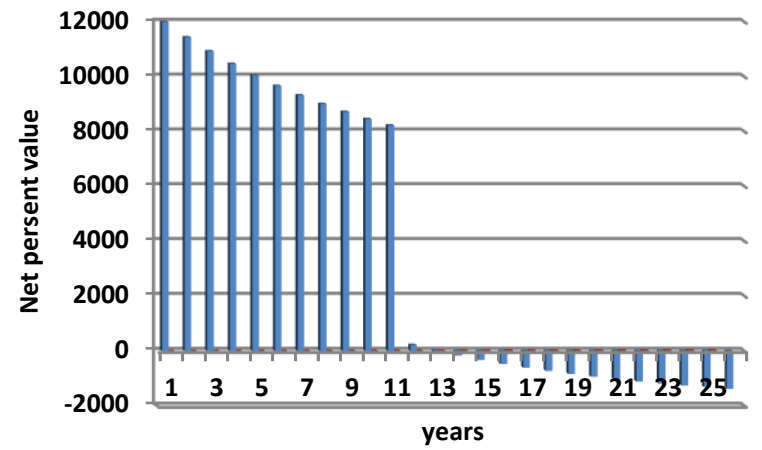

Fig 7. Commulative Cash flow

\section{References}

[1] F- Banat, Qiblawey, H. and Al-Nasser, Q.;" Design and Operation of Small-Scale Photovoltaic-Driven Reverse Osmosis (PV-RO) Desalination Plant for Water Supply in Rural Areas " Published Online October 2012 (http://www.SciRP.org/journal/cweee)

[2] Wafiq- A.and Ahmed, M.W.;" Solar Energy: Solution to Fuel dilemma" Marine \& Offshore Engineering Technology Conference.

[3] M. A. Omran .; " Analysis of solar radiation over Egypt " Theor. Appl. Climatol. 67, 225 \pm 240 (2000)

[4] El-Menchawy, A. Bassioni, H. and Farouk, A. A.;" Photovoltaic Systems in Existing Residential Building in Egypt", International Journal of Scientific \& Engineering Research Volume 2, Issue 7, July-2011 1ISSN 2229-5518

[5] El-zeftawy. A. Gado, A.;" Design and Operating Photovoltaic Power Sysytem-Interactive the Electric Utility to Supply Residential Loads in Egypt|" , $20^{\text {th }}$ International Conference on Electricity Distribution Prague, 8-11 June 2009

[6] Hazelton, M.; "Lobitos Solar Energy (PV) Feasibility Study" MSc. Renewable Energy (Newcastle University UK) EcoSwell 2015

[7] A. Gado, El-zeftawy. A.;" Design and Economy of Renewable Energy Sources to Supply Isolated Loads at Rural and Remote Areas of Egypt".20 ${ }^{\text {th }}$ International Conference on Electricity Distribution Prague, 8-11 June 2009

[8] Tzouanas, C. N., Tzouanas,V.;" Study of a Photo-voltaic (PV) System Using Exel: Economic Analysis, Modeling, Simulation, and Optimization 